\section{IDENTIFICATION OF GASTROINTESTINAL HELMINTHS INFECTION FROM GOATS ISOLATED IN A FARM IN KUANTAN, PAHANG, MALAYSIA}

\author{
Mawaddah Mohd Azlana, Afzan Mat Yusofb, Mardhiah \\ Mohammada*
}

aDepartment of Biomedical Science, Kulliyyah of Allied Health Sciences, International Islamic University Malaysia, Jalan Sultan Ahmad Shah, Bandar Indera Mahkota, 25200, Kuantan, Pahang Darul Makmur, Malaysia

bDepartment of Basic Medical Sciences, Kulliyyah of Nursing, International Islamic University Malaysia, Jalan Sultan Ahmad Shah, Bandar Indera Mahkota, 25200 Kuantan, Pahang Darul Makmur, Malaysia
Article history

Received

20 December 2017

Received in revised form

5 September 2018

Accepted

1 October 2018

Published online

15 December 2018

*Corresponding author mmoh@iium.edu.my

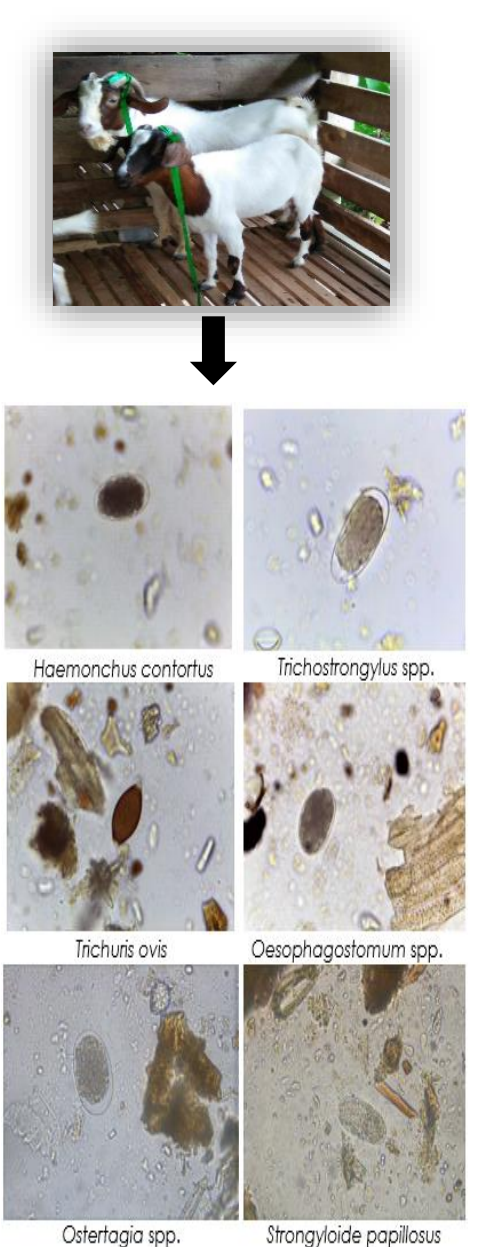

Ostertagia spp.

\begin{abstract}
Livestock is a group of domesticated animal that is reared in an agricultural setting. It usually served as a source of income for most peoples in Malaysia. However, the productions of this livestock especially goats have been decreasing due to the occurrence of gastrointestinal helminths infection. The aim of this study was to identify the presence and species of gastrointestinal helminths from 120 fecal samples collected directly from the rectum of goats from a farm located in Kuantan, Pahang. Firstly, the physical observation was evaluated on all goats. Then, their fecal sample was examined within 96 hours using Formal-ether Sedimentation method for the morphological characteristics identification of gastrointestinal helminthic species under the microscope. This study has identified the majority of goats with a good physical condition, that they have no sign of blood loss and have appropriate body frame. However, the microscopic identification has revealed 89 from the total samples positive with gastrointestinal helminths species while 76 of the positive showed presence of mixed species. The species found were Haemonchus contortus, Trichostrongylus spp., Trichuris ovis, Oesophagostomum spp., Ostertagia spp., and Strongyloides papillosus. This high infection of gastrointestinal helminths observed in goats is related to an impaired immune system, poor farm management, and uncontrolled anthelmintic treatment. The presence of various species of gastrointestinal helminths within a goat is an important cause of morbidity and loss of production. Therefore, this study suggested the need for an effective system of management, diagnosis and appropriate treatment that can reduce the risk of infection and increase the productivity of the animals.
\end{abstract}

Keywords: Gastrointestinal helminthes, goats, physical observation, formal-ether sedimentation method, microscopic identification

\section{Abstrak}

Ternakan adalah sekumpulan haiwan peliharaan yang diternak dalam keadaan pertanian di mana ia berfungsi sebagai sumber pendapatan bagi kebanyakan orang di Malaysia. Walau bagaimanapun, pengeluaran ternakan telah berkurang disebabkan oleh jangkitan cacing di usus haiwan. Tujuan kajian ini adalah untuk mengenal pasti kehadiran dan jenis cacing di usus dari 120 sampel najis yang dikumpulkan secara langsung dari rektum kambing dari sebuah ladang yang terletak di Kuantan, Pahang. Pertama sekali, pemeriksaan fizikal ke atas setiap kambing telah dilakukan. Selepas itu,
\end{abstract}


setiap sampel najis kambing tersebut telah diperiksa dalam masa 96 jam menggunakan teknik permendapan formal-ether untuk mengenal pasti sifat-sifat bentuk setiap spesies cacing usus di bawah mikroskop. Pemeriksaan fizikal kambing menunjukkan bahawa hampir setiap dari mereka tiada tanda-tanda kekurangan darah dan mempunyai bentuk badan yang bersesuaian. Walau bagaimanapun, pemerhatian mikroskop menunjukkan kehadiran cacing usus pada 89 ekor kambing dengan 76 ekor daripadanya mempunyai lebih dari satu spesies cacing usus. Spesies yang ditemui ialah Haemonchus contortus, Trichostrongylus spp., Trichuris ovis, Oesophagostomum spp., Ostertagia spp., dan Strongyloides papillosus. Peningkatan jangkitan cacing usus pada kambing biasanya berkait dengan kelemahan sistem imun, pengurusan ladang dan rawatan ubat anthelmintic yang tidak terkawal. Kehadiran pelbagai spesies cacing usus adalah salah satu penyebab yang menyumbang kepada morbiditi dn kekurangan pengeluaran. Oleh itu, kajian ini mengenal pasti keperluan untuk sistem pengurusan, diagnosis dan rawatan berkesan dengan ubat anthelmintik yang dapat mengurangkan risiko jangkitan dan meningkatkan produk pengeluaran ternakan.

Kata kunci: Cacing usus, kambing, pemeriksaan fizikal, pemendapan formal-ether, pengenalpastian mikroskopik

(C) 2019 Penerbit UTM Press. All rights reserved

\subsection{INTRODUCTION}

Livestock industries are one of the important agriculture sectors in Malaysia. In 2015, it has contributed about $18 \%$ of the sector Gross Domestic Product (GDP) in Malaysian economic development and an increase of work opportunities [1]. Small ruminant production, especially goat farming, has become an additional source of income mostly in the rural area. Even though goats are believed to have a great adaptability in certain environmental condition but the farmers are dealing with a bigger challenge of lower capital investment and high production costs [2]. It is estimated the total number of goat reared in Malaysia in 2016 is 446,854 goats compared to 2015 and 2014 with 431,651 and 429,398 respectively. In Pahang, it is estimated that approximately 35,499 goats were reared in 2016 [3]. The increasing trend in the number indicates that goat farming has played an important role in Malaysian agriculture for many years. Estimation of consumption of Mutton products among Malaysian since 2007 until 2016 is about 41,425.10 metric tonnes per capita and is expected to increase [4]. Currently the Malaysian are seeking an alternative way to achieve balanced and healthier meals such as mutton due to its substantially fewer calories, fat, and cholesterol when compared to beef, pork, and chicken. The continuous effort to fulfill the demand of increasing world populations is however faced with many obstacles among which are diseases caused by intestinal helminths [5]. The increased infections of parasitic intestinal helminths become one of economic and welfare burden to the global ruminant livestock industry. Infected animals will result in reduced weight gains, reduced food conversion rates, abortion, infertility and reduced meat and milk production rates [6]. If the helminths are not controlled and eliminated, the infection eventually lead to the increase of morbidity, mortality and economic losses [7].
Gastrointestinal helminthiasis, a condition of infection by the parasitic worm in any parts of gastrointestinal tract occurred due to one or more species of intestinal helminths are acquired by the ingestion of infective eggs or larvae or by skin penetration [8]. The most common species of gastrointestinal helminths found in goat along Peninsular Malaysia are Heamonchus contortus, Trichostringylus spp., Oesophagostomum spp., Ostertagia spp., and Trichuris ovis [9]. It further proves that gastrointestinal strongylid nematodes were the most prevalence helminths that infected goats based on several studies conducted in Asian region such as Malaysia, Philippines, China, India, Indonesia $[10,11,12,13,14,15,16]$.

At the moment parasitic infection studies that were conducted in East Coast Malaysia were limited to one out of three states which is Terengganu and only focusing on the small area of helminths infection. For example, a study by Khadijah et al. (2014) [17] has identified parasitic infection in goats from two separate farms in Kuala Terengganu. Meanwhile, two other related studies were to identify the relationship of intensity of the infection and age $[18,19]$.

Information on the current status of gastrointestinal helminths infection in goats in other states of East Coast region still inadequate. These information are essential for the farmers in order to control the infection and prevent severe cases of mortality. Thus, the aim of this study was to determine and to identify the presence and species of gastrointestinal helminths isolated from the collected goat's fecal sample.

\subsection{METHODOLOGY}

\subsection{Area Description}

The study was conducted between August and October 2016 in a farm, located in Kuantan, Pahang, Malaysia. 


\subsection{Sample Collection and Analysis}

Ethical clearance was obtained from Institutional Animal Care and Use Committee (IACUC), International Islamic University Malaysia (IIUM) (IIUM/IACUC Approval/2016/ (12) (79)). A total of 120 goats age range from nine months until two years old were selected randomly from a farm located in Kuantan, Pahang. Fresh fecal samples were collected directly from the rectum of each goat and kept in stool container, labelled and stored at $4^{\circ} \mathrm{C}$ until examined. Each sample was visually examined for its color and consistency. During the collection, the body condition of each goat and the farm environment and management were also observed and recorded.

\subsection{Goat Physical Observation}

The physical observation was done carefully after the fecal sampling on each goat based on the method developed by Bath \& Van Wyk, 2009 [20]. The method is known as the Five Point Check@ which indicate five different parts of the body for observation. They are Eye, Jaw, Back (Body Condition), Rear (Dag Score) and Coat. Then, the goats were classified into three group based on the condition of the observational body parts. First group is "acceptable/normal/best" (smooth and rounded body, absent of anemia, fecal soiling, submandibular edema and best coat coverage), second group is "Borderline/thin/moderate" (obvious bone frame, slightly or moderate fecal soiling, anemic, submandibular edema and average coat coverage); and third group is "Dangerous/ fat/abnormal/less" (smooth, thick and more rounded body frame, severe anemia, fecal soiling, present of submandibular edema and less coat coverage).

\subsection{Detection of Helminths}

Samples were examined individually for the presence of gastrointestinal helminths using formalin-ether sedimentation technique. The protocols were conducted based on the method adapted from Paniker (2013) [21]. The technique was proven to provide certain advantages including little distortion on organism's cell wall as well as enhanced in the recovery of helminths egg and larvae [22]. Briefly, 10 $\mathrm{ml}$ of formal-fecal suspension was strained through a brass wire sieve into $15 \mathrm{ml}$ centrifuge tube. Then, diethyl ether was added to a volume of $13 \mathrm{ml}$. The suspension was thoroughly mixed and centrifuged at $300 \mathrm{rpm}$ for 1 minute. After loosening the debris plug, the top three layers were decanted, the pellet was resuspended with a drop of formalin and slides were prepared for examination. Gastrointestinal helminths eggs were identified under the light microscope with $40 \mathrm{X}$ magnification based on its morphological shape characteristics [23].

\subsection{RESULTS AND DISCUSSION}

All goats had undergone the physical observation at five different body parts. These observations would reveal symptoms that may lead to disease. Anemia and blood loss can be indicated by evaluating the color of the lower lid on the eyes. Whereas by observing on the present of accumulation of fluid under lower jaw would indicate the presence of a condition called bottle jaw. At the same time, the body condition was identified by observing the availability of spinous process, rib cage with the thickness of fat in loin eye. Meanwhile, the evidence of diarrhea can be evaluated by the presence of fecal soiling at the tail, leg or hocks. Lastly, assessing the body hair condition would indicate in the overall health and thriftiness of farm management. The conditions were then classified into "acceptable / normal / best", "borderline / thin / moderate" and "dangerous / fat / abnormal / less" as showed in Figure 1.

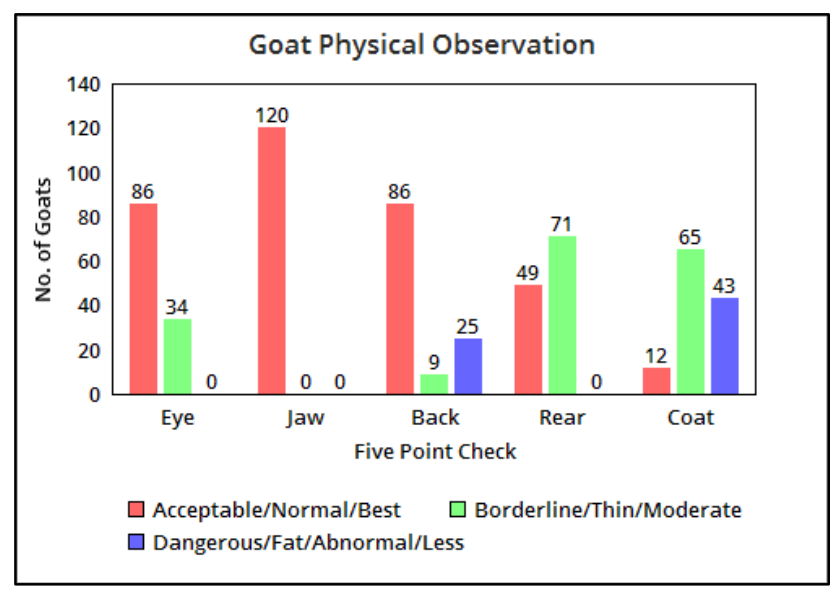

Figure 1 Goats physical observation at five-point check of the body (Eye, Jaw, Back (Body condition), Rear (Dag score) and Coat) $(n=120)$

The observation showed that $71.67 \%$ goats showed no sign of blood loss and in a good body condition (back), meanwhile $28.33 \%$ and $7.50 \%$ indicated the moderate sign of blood loss and thin body condition (back) respectively. Present or absent of blood loss was being determined by looking at the color of lower eyelid ranging from red to white. Then, the investigation on the rear side of the goats indicated $59.17 \%$ of them have moderate fecal soiling and only $40.83 \%$ of them exhibit no fecal soiling. Simultaneously, the coat hair coverage evaluation identified that only $10 \%$ of the total goats have the best coverage while $54.17 \%$ have moderate coverage. In addition, all goats showed no indication of accumulation of fluid under lower jaw (bottle jaw). However, another $20.83 \%$ and $35.83 \%$ fall into the dangerous group of fat body condition score (BCS) and less coat hair coverage respectively. 
As summarized in Table 1, the study found $74.17 \%$ of the goats $(89 / 120)$ were positive with gastrointestinal helminths. the positive samples were studied further, which revealed $63.33 \%(76 / 89)$ of mixed infection of more than two species of gastrointestinal helminths species. Haemonchus contortus was identified as predominant species infecting the goats with the percentage of $63.33 \%(76 / 120)$. Other gastrointestinal helminths species found were Trichostrongylus spp. (47.50\%), Ostertagia spp. (40.83\%), Oesophagostomum spp. (39.17\%), Trichuris ovis (22.50\%) and Strongyloides papillosus (10.83\%) (Table 2). Each species of gastrointestinal helminths was differentiated based on its morphological characteristic and shape (Figure 2-Figure 7).

Table 1 Overall infection of gastrointestinal helminths in goat fecal sample

\begin{tabular}{lcc}
\hline & \multicolumn{2}{c}{ Fecal Sample (n= 120) } \\
\cline { 2 - 3 } & No. & \% \\
\hline Positive Infection & 89 & 74.17 \\
Negative Infection & 31 & 25.83 \\
Mixed Infection & 76 & 63.33 \\
\hline
\end{tabular}

Table 2 Species diversity of gastrointestinal helminths found in goat fecal samples $(n=89)$

\begin{tabular}{lcc}
\hline & \multicolumn{2}{c}{$\begin{array}{c}\text { Gastrointestinal Helminth } \\
\text { Species }\end{array}$} \\
\cline { 2 - 3 } & No. & $\%$ \\
\hline Haemonchus contortus & 76 & 63.33 \\
Trichostrongylus spp. & 57 & 47.50 \\
Ostertagia spp. & 49 & 40.83 \\
Oesophagostomum spp. & 47 & 39.17 \\
Trichuris ovis & 27 & 22.50 \\
Strongyloides papillosus & 13 & 10.83 \\
\hline
\end{tabular}

The sampling for the study was done randomly, however, the goats were selected in the range of age from nine months until two years old. At this age of growing period, the goat starts to increase in their blood volume. Thus it is easy to identify which goat that has been infected with gastrointestinal helminths whenever they experience blood loss. Besides, these goats are also at the age stage where they are easily suffered from malnutrition, making them more susceptible to helminths infection [24]. Raza et al. (2014) [25] reported that $81.97 \%(241 / 294)$ of goats below 18 months old were infected with gastrointestinal helminths. Meanwhile, a study by Kelemework et al. (2016) [26] found no difference in the rates of gastrointestinal helminths infection between young and adult goats. In facts, the infection commonly happens in young goat due to weak immunological response. Nevertheless, the adult goat that has developed resistance towards helminths could serve as sources of infection to the susceptible group.

The goat physical observation or Five Point Check@ (5. (๑) is another method for monitoring the presence of internal parasite [20]. This checklist was intended to further isolated animal for Target Selective Treatment
(TST), a system that selects the animal for treatment according to the criteria provided (Van Wyk \& Bath, 2002) [27]. When the animal is selected for TST, those that most likely needed the treatment are included and those least needed are immediately excluded. Besides that, TST also slows the development of anthelmintic resistance [28]. However, at the same time, it can also serve as immediate observation of goats that have internal parasite infection [29]. This is because when the five-point check is combined, it represents the clinical signs that normally seen in parasitized animals [30].

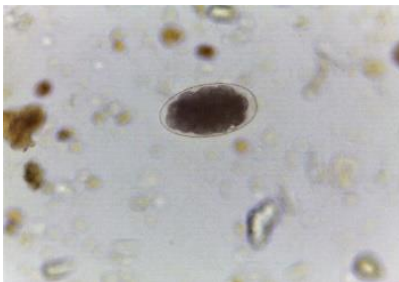

2. Haemonchus contortus

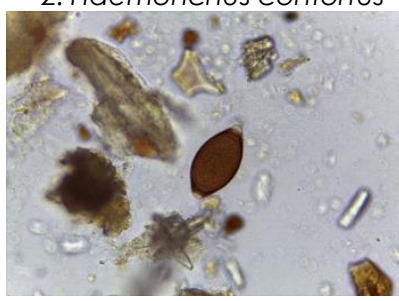

4. Trichuris ovis

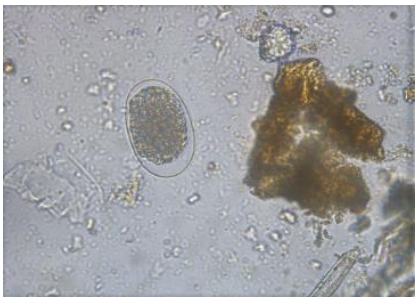

6. Ostertagia spp.

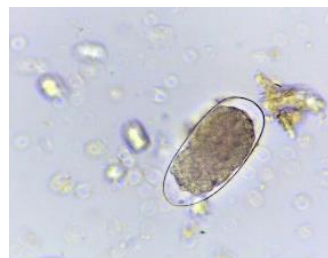

3. Trichostrongylus spp.

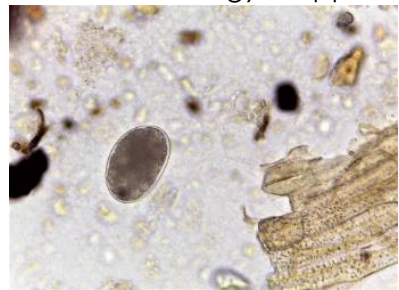

5.Oesophagostomum spp.

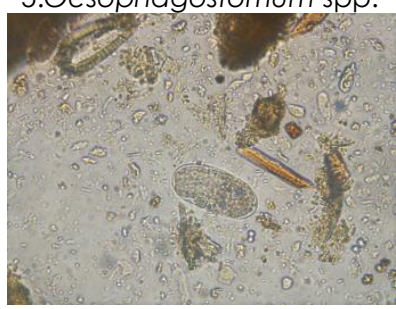

7. Strongyloide papillosus
Figure 2-7 Diverse species of gastrointestinal helminths eggs of goats (x40) [(2)Haemonchus contortus, (3)Trichostrongylus spp., (4)Trichuris ovis, (5)Oesophagostomum spp., (6)Ostertagia spp., (7)Strongyloide papillosus]

Microscopic and physical observation in each goat were compared and revealed no significance in terms of the presence of various gastrointestinal helminths species. The microscopic examination showed overall infected goats are $74.17 \%$. Despite the observational purpose, the result indicated that $58.83 \%$ of goats are in normal condition with the smooth and round body, good coat quality, absent of anemia in the eyes, submandibular edema, and fecal soiling. Meanwhile, $29.83 \%$ and $11.3 \%$ of goats experienced moderate and dangerous condition respectively. The animal with heavy infection of internal parasite often result in poor body condition, unfortunately, there is some goat that showed no change in body condition except for slight weight loss till the day it dies [31].

Current study disclosed that the overall occurrence of gastrointestinal helminths found in 
goats from Kuantan, Pahang was $74.17 \%$ (89/120). This finding was closely related to the results reported by Mat Yusof \& Md Isa (2016) [19] and Tan et al. (2014) [10] in Malaysia with $77.70 \%$ and $63.10 \%$ infection respectively. Besides that, it is also in agreement with studies done in China [14] and Bangladesh [32] with $79.90 \%$ and $74.55 \%$ infection respectively. However, this finding is comparatively lower than the study by Sylvia et al. (2015) [33] in South Western Nigeria with $96.70 \%$ gastrointestinal helminths infection in goat. This differences in occurrences could possibly be related to the variation in sample size, geographical and climatic condition during the study that may affect the survival and development of infective larvae of the helminths. High infection of gastrointestinal helminths observed in goats is usually related to retarded immune development with the addition of poor nutrition intake and uncontrolled anthelmintic treatment [34].

Based on the microscopic finding, six different species of gastrointestinal helminths were identified and that there are evident of mixed infections of species. Many previous study by Ma et al. (2014) [13], Khadijah et al. (2014) [17], Gorski et al. (2004) [35], Ayaz et al. (2013) [36] and Jittapalapong et al. (2012) [37] reported on similar outcomes of the multiple infection of gastrointestinal helminths species in goats. Poor farm management such as unhygienic shelter or contaminated pasture and water may contribute to multiple infections of gastrointestinal helminths species within a goat [25].

Infection with various species of gastrointestinal helminths within a goat is an important additional cause of morbidity and loss of production [38]. The presence of interaction between the gastrointestinal helminths species will cause an impairment in host immune system thus causing an increase in goat susceptibility to other diseases or parasites [39]. Besides that, the infection worsens when each of the gastrointestinal helminths species has different level of resistance causing a reduction in response towards treatment given due to heritable changes in genetic [40]. These conditions are somehow becoming a threat to the agricultural sector [41].

It is apparent that the highest occurrences of gastrointestinal helminths species found in goats are Haemonchus contortus and Trichostrongylus spp. with $63.33 \%$ and $47.50 \%$ respectively. Previous study conducted in Malaysia [10, 42, 43, 44], Indonesia [16, 45], India [15], and Philippines [12] had also reported these similar species as the most predominant. Environment condition such as warm, humid and rainy climate has become an advantage to these species compared to the other helminths [46]. Haemonchus contortus is known to have the ability to produce thousands of eggs per day and has a relatively short generation interval [47]. They reside in the abomasum of the goats and has a vicious ability to suck blood from its host. Both larvae and adult worm feed on blood and with constant exposure, it can eventually cause a considerable damage to the stomach tissue [24]. Meanwhile, adult Trichostrongylus spp. lay eggs in the large intestines which then shed out the host in feces. It can develop into infective larvae just in five to seven days and able to remain infective up to six months. They attached to the goat's small intestine and drawn blood from the intestinal lining thus causing irritation and swelling which result in malabsorption, impaired digestion and protein loss [23]. Therefore, this justifies an urgent need for the investigation of the occurrences of gastrointestinal helminths in goats with the hope that appropriate measures can be imposed and losses can be reduced.

\subsection{CONCLUSION}

This study had shown that goats in this farms are commonly infested with the variety of gastrointestinal helminth with a high infection of Heamonchus contortus species followed by Trichostrongylus spp., Trichuris ovis, Oesophagostomum spp., Ostertagia spp., and Strongyloides papillosus. The finding suggests that prevention measure and usage of anthelmintic should be implemented properly to reduce the parasitic burden on the goats. At the same time, education on animal farming should be provided to the farm owner from time to time. It is very important to control the infection since infected goats might result in production losses through mortality that leads to economic loss. Moreover, proper pasture and animal management could improve the animal health thus increases the production, reduce treatment cost, and indirectly increase farmers profit. Further studies on the helminths load in goat and investigation on more farms should be carried out to confirm the prevalence of gastrointestinal helminth in goats.

\section{Acknowledgement}

This study is funded by Ministry of Higher Education RAGS grant no 15-056-0119. The authors would like to express their gratitude and appreciation for the science officers of Kulliyyah of Allied Health Science and Integrated Centre for Research Animal Care and Use (ICRACU) for their assistance and support in various ways throughout the study. We would also express our gratitude to the respective farm owner and handler for their cooperation during this study.

\section{References}

[1] Malaysia Productivity Corporation (MPC). 2015. 22 nd Productivity Report 2014/2015: Chapter: Productivity Performance of Agriculture Sector. Malaysia: Malaysia Production Corporation, Ministry of International Trade and Industry. Retrieved from http://www.miti.gov.my/index.php/pages/view/1771.

[2] Aziz, M. A. 2010. Present Status of the World Goat Populations and Their Productivity. Lohmann Information. 45(2): 42-52. Retrieved from http://www.lohmanninformation.com/content/____45_artikel17.pdf. 
[3] Department of Veterinary Services. 2017. Malaysia: Livestock Population, 2016 Retrieved from http://www.dvs.gov.my/index.php/pages/view/1743.

[4] Department of Veterinary Services. 2017. Malaysia: Consumption of Livestock Product, 2007-2016 http://www.dvs.gov.my/index.php/pages/view/1743.

[5] FAO (Food and Agriculture Organization of the United Nations). 2009. How to Feed the World in 2050. Rome: HighLevel Expert Forum. Retrieved from http://www.fao.org/home/en/.

[6] Tisdell, C. A., Harrison, S. R., \& Ramsay, G. C. 1999. The Economic Impacts of Endemic Diseases and Disease Control Programmed. Revue Scientifique et TechniqueOffice International des Epizooties. 18(2): 380-398.

DOI: https://doi.org/10.20506/rst.18.2.1168.

[7] Sangster, N. 2007. Topic 3: How Parasites Affect Production. Retrieved

from http://sydney.edu.au/vetscience/sheepwormcontrol/topi cs/topic3.html.

[8] Githigia, S. M., Thamsborg, S. M., Munyua, W. K., \& Maingi, N. 2001. Impact of Gastrointestinal Helminths on Production in Goats in Kenya. Small Ruminant Research. 42(1): 21-29. DOI: https://doi.org/10.1016/s0921-4488(01)00240-1.

[9] Sani, R. A., Adnan, M., Cheah, T. S., \& Chandrawathanf, P. 2004. Helminth Control for Small Ruminants in Malaysia. J. Vet. Malaysia. 16(1\&2): 1-8. Retrieved from http://psasir.upm.edu.my/41472/.

[10] Tan, T. K., Panchadcharam, C., Low, V. L., Lee, S. C., Ngui, R., Sharma, R. S., \& Lim, Y. A. 2014. Co-infection of Haemonchus contortus and Trichostrongylus spp. Among Livestock in Malaysia as Revealed by Amplification and Sequencing of the Internal Transcribed Spacer II DNA Region. BMC Veterinary Research. 10(1): 1-7. DOI: https://doi.org/10.1186/1746-6148-10-38

[11] Zainalabidin, F. A., Raimy, N., Yaacob, M. H., Musbah, A., Bathmanaban, P., Ismal, E. A., Mamat, Z. C., Zahari, Z., Ismail, M. I., \& Panchadcharam, C. 2015. The Prevalence of Parasitic Infestation of Small Ruminant Farms in Perak, Malaysia. Tropical Life Sciences Research. 26(1): 1-8. Retrieved from http://www.tlsr.usm.my/.

[12] Rupa, A. P. M., \& Portugaliza, H. P. 2016. Prevalence and Risk Factors Associated with Gastrointestinal Nematode Infection in Goats Raised in Baybay City, Leyte, Philippines. Veterinary World. 9(7): 728-734. DOI: https://doi.org/10.14202/vetworld.2016.728-734.

[13] Ma, J., He, S. W., Li, H., Guo, Q. C., Pan, W. W., Wang, X. J., Zhang, J., Liu, L. Z., Liu, W., \& Liu, Y. 2014. First Survey of Helminths in Adult Goats in Hunan Province, China. Tropical Biomedicine. $31(2)$ : 261-269. Retrieved from http://msptm.org/tropical-biomedicine/.

[14] Yang, X., Gasser, R. B., Fang, R., Zeng, J., Zhu, K., Qi, M., Zhang, Z., Tan, L., Lei, W., Zhou, Y., Zhao, J., \& Hu, M. 2016. First Survey of Parasitic Helminths of Goats along the Han River in Hubei Province, China. Acta Parasitologica. 61 (3): 602-606. DOI: https://doi.org/10.1515/ap-2016-0080.

[15] Singh, A. K., Das, G., Roy, B., Nath, S., Naresh, R., \& Kumar, S. 2016. Prevalence of Strongyle Infections in Goat of Maha Koushal Region, Madhya Pradesh, India. Journal of Parasitic Diseases. 40(2): 289-291. DOI: https://doi.org/10.1007/s12639-014-0496-5.

[16] Domba, K. 2005. Gastrointestinal Nematode Infections on Sheep and Goats in West Java, Indonesia. JITV. 10(4): 293$304 . \quad$ Retrieved from http://medpub.litbang.pertanian.go.id/index.php/jitv/arti $\mathrm{cle} / \mathrm{view} / 456$.

[17] Khadijah, S., Andy, T. F. H., Khadijah, S. S. A. K., \& Khairi, A. K. M. 2014. Parasite Infection in Two Goat Farms Located in Kuala Terengganu, Peninsular Malaysia. Asian Journal of Agriculture and Food Sciences. 2(06): 463-467. Retrieved from

https://ajouronline.com/index.php/AJAFS/article/view/20 75.
[18] Hisamuddin, N. H., Hashim, N., Soffian, S. N., Raja Abdul Rahman, R. N. R. I., Mohammad, M., Md Isa, M. L., \& Mat Yusof, A. 2016. The Identification of Helminths and Coccidia from Goats in Two Farms in Kuala Terengganu, Malaysia. Jurnal Teknologi. 78(9): 9-12.

DOI: https://doi.org/10.11113/jt.v78.7624.

[19] Yusof, A. M., \& Isa, M. L. M. 2016. Prevalence of Gastrointestinal Nematodiasis and Coccidiosis in Goats from Three Selected Farms in Terengganu, Malaysia. Asian Pacific Journal of Tropical Biomedicine. 6(9): 735-739. DOI: https://doi.org/10.1016/j.apjtb.2016.07.001.

[20] Bath, G. F., \& Van Wyk, J. A. 2009. The Five Point Check@ for Targeted Selective Treatment of Internal Parasites in Small Ruminants. Small Ruminant Research. 86(1): 6-13. DOI: https://doi.org/10.1016/j.smallrumres.2009.09.009.

[21] Paniker. 2013. Paniker's Textbook of Medical Parasitology. $7^{\text {th }}$ ed. India: Jaypee Brothers Medical Publishers (P) Ltd. DOI: https://doi.org/10.5005/ip/books/12069.

[22] Truant, A. L., Elliott, S. H., Kelly, M. T., \& Smith, J. H. 1981. Comparison of Formalin-Ethyl Ether Sedimentation, Formalin-Ethyl Acetate Sedimentation, and Zinc Sulfate Flotation Techniques for Detection of Intestinal Parasites. Journal of Clinical Microbiology. 13(5): 882-884. DOI: 0095-1 137/81/050882-03\$02.00/0.

[23] Taylor, M. A., Coop, R. L., Wall, R. L. 2015. Veterinary Parasitology. $4^{\text {th }}$ ed. London: Blackwell Publishing Ltd. DOI: https://doi.org/10.1002/9781119073680.

[24] Heath, S. E., \& Harris Jr, B. 2003. Common Internal Parasites of Goats in Florida. Circular-Florida Cooperative Extension Service (USA). Retrieved from http://ufdcimages.uflib.ufl.edu/IR/00/00/47/78/00001/DS16 400.pdf.

[25] Raza, M. A., Younas, M., \& Schlecht, E. 2014. Prevalence of Gastrointestinal Helminths in Pastoral Sheep and Goat Flocks in the Cholistan Desert of Pakistan. The Journal of Animal \& Plant Sciences. 24(1): 127-134. Retrieved from http://www.thejaps.org.pk/.

[26] Kelemework, S., Tilahun, A., Benalfew, E., \& Getachew, A. 2016. A Study on Prevalence of Gastrointestinal Helminthiasis of Sheep and Goats in and Around Dire Dawa, Eastern Ethiopia. Journal of Parasitology and Vector Biology. 8(10): 107-113. DOI: $10.5897 / J P V B 2016.0245$.

[27] Van Wyk, J. A., \& Bath, G. F. 2002. The FAMACHA System for Managing Haemonchosis in Sheep and Goats by Clinically Identifying Individual Animals for Treatment. Veterinary Research. 33(5): 509-529. DOI: https://doi.org/10.1051/vetres:2002036.

[28] Kenyon, F., Greer, A. W., Coles, G. C., Cringoli, G., Papadopoulos, E., Cabaret, J., Berrag, B., Varady, M., Van Wyk, J. A., Thomas, E., Vercruysse, J., \& Jackson F. 2009. The Role of Targeted Selective Treatments in the Development of Refugia-Based Approaches to the Control of Gastrointestinal Nematodes of Small Ruminants. Veterinary Parasitology. 164(1): 3-11. DOI: 10.1016/j.vetpar.2009.04.015.

[29] Hale, M. 2015. Managing Internal Parasite in Sheep and Goat. ATTRA Sustainable Agriculture. Retrieved from https://attra.ncat.org/attra-pub/viewhtml.php?id=215\#6.

[30] Coffey, L., \& Hale, M. 2012. Tools for Managing Internal Parasites in Small Ruminants: Pasture Management. ATRA National Sustainable Agriculture Information Service. Retrieved from www.attra.ncat.org.

[31] Stille, M. T. 2006. The Goat Care Handbook. $2^{\text {nd }}$ Ed. USA: McFarland \& Company Inc. Retrieved from https://books.google.com.my/books?id=q7WQBAAAQBA $\mathrm{J} \&$ source $=$ gbs navlinks $\mathrm{s}$.

[32] Islam, K. B. M. S., \& Taimur, M. J. F. A. 2008. Helminthic and Protozoan Internal Parasitic Infections in Free Ranging Small Ruminants of Bangladesh. Slov Vet Res. 45(2): 67-72. Retrieved from http://www.slovetres.si/index.php/SVR.

[33] Sylvia, O. U., Oluwole, A. S., Oladeji, M. H., Abdulhakeem, A. A., Alabi, O. M., \& Friday, E. U. 2015. Gastrointestinal Helminth Infections in a Ruminant Livestock Farm in 
Abeokuta, South Western Nigeria. Annual Research \& Review in Biology. 8(4): 1.

DOI: https://doi.org/10.9734/arrb/2015/18812.

[34] Kumar, N., Rao, T. K. S., Varghese, A., \& Rathor, V. S. 2013. Internal Parasite Management in Grazing Livestock. Journa of Parasitic Diseases. 37(2): 151-15.

DOI: 10.1007/s12639-012-0215-z.

[35] Gorski, P., Niznikowski, R., Strzelec, E., Popielarczyk, D. Gajewska, A., \& Wedrychowicz, H. 2004. Prevalence of Protozoan and Helminth Internal Parasite Infections in Goat and Sheep Flocks in Poland. Archiv Fur Tierzucht. 47(6; SPI): 43-49. Retrieved from http://www.archanimbreed.com/.

[36] Ayaz, M. M., Raza, M. A., Murtaza, S., \& Akhtar, S. 2013. Epidemiological Survey of Helminths of Goats in Southern Punjab, Pakistan. Trop. Biomed. 30(1): 62-71. Retrieved from http://msptm.org/tropical-biomedicine/.

[37] Jittapalapong, S., Saengow, S., Pinyopanuwat, N., Chimnoi, W., Khachaeram, W., \& Stich, R. W. 2012 Gastrointestinal Helminthic and Protozoal Infections of Goats in Satun, Thailand. Journal Tropical Medicine and Parasitology. 35(2): 48-54. Retrieved from http://www.ptat.org/uploads/pdf/journalPdf_35-2-2012e2.pdf.

[38] Kumsa, B., Tadesse, T., Sori, T., Dugum, R., \& Hussen, B. 2011 Helminths of Sheep and Goats in Central Oromia (Ethiopia) During the Dry Season. Journal of Animal and Veterinary Advances. 10(14): 1845-1849. DOI: https://doi.org/10.3923/javaa.2011.1845.1849.

[39] Wang, C. R., Qiu, J. H., Zhu, X. Q., Han, X. H., Ni, H. B., Zhao, J. P., Zhou, Q. M., Zhang, H. W., \& Lun, Z. R. 2006. Survey of Helminths in Adult Sheep in Heilongjiang Province, People's Republic of China. Veterinary Parasitology. 140(3): 378-382. DOI: https://doi.org/10.1016/j.vetpar.2006.04.008.

[40] Shalaby, H. A. 2013. Anthelmintics Resistance; How to Overcome It? Iranian Journal of Parasitology. 8(1): 18-32. Retrieved from http://ijpa.tums.ac.ir/index.php/ijpa.
[41] Lalchhandama, K. 2010. Anthelmintic Resistance: The Song Remains the Same. Sci Vis. 10(4): 111-22. Retrieved from www.sciencevision.info.

[42] Mursyidah, A. K., Khadijah, S., \& Rita, N. 2017. Nematode in Small Ruminants and the Management of the Farms in Terengganu, Peninsular Malaysia. Tropical Biomedicine. 34(1): 59-65. Retrieved from http://msptm.org/tropicalbiomedicine/.

[43] Dorny, P., Symoens, C., Jalila, A., Vercruysse, J., \& Sani, R. 1995. Strongyle Infections in Sheep and Goats Under the Traditional Husbandry System in Peninsular Malaysia. Veterinary Parasitology. 56(1-3): 121-136.

DOI: https://doi.org/10.1016/0304-4017(94)00657-x.

[44] Rahman, W. A., \& Che Ros, A. 1992. Observations on the Worm Egg Counts and Their Nematode Species in Goats from the North-East District of Penang Island, Peninsular Malaysia. Pertanika. 15(3): 221-221. Retrieved from http://psasir.upm.edu.my/3028/.

[45] Hanafiah, M., Winaruddin, \& Rusli. 2002. Studi Infeksi Nematoda Gastrointestinal Pada Kambing Dan Domba Di Rumah Potong Hewan Banda Aceh= Study of Gastrointestinal Nematodes Investing Goats and Sheep at The Banda Aceh Slaughterhouse. Jurnal Sain Veteriner. 20(1): 15-19. DOI: https://doi.org/10.22146/jsv.389.

[46] Khajuria, J. K., Katoch, R., Yadav, A., Godara, R., Gupta, S. K., \& Singh, A. 2013. Seasonal Prevalence of Gastrointestinal Helminths in Sheep and Goats of Middle Agro-Climatic Zone of Jammu Province. Journal of Parasitic Diseases. $37(1): 21-25$ DOI: https://doi.org/10.1007/s12639-012-0122-3.

[47] Maria, L., L., B. 2006. Haemonchus contortus (Barber Pole Worm) Infestation in Goats. Your Experts for Life, Alabama A\&M University. 1-4. Retrieved from http://www.aces.edu/pubs/docs/U/UNP-0078/UNP0078.pdf. 